\title{
BIOREMEDIATION OF OCDF-CONTAMINATED SOILS BY NOVEL BACTERIAL STRAIN
}

\author{
Lin, J. L. ${ }^{1}-$ ChEn, S. C. ${ }^{2}-$ Sung, W. P. ${ }^{3}-$ ChEn, T. Y. ${ }^{3}-$ SurAmpalli, R. Y. ${ }^{4}-$ KAO, C. M. ${ }^{1 *}$ \\ ${ }^{1}$ Institute of Environmental Engineering, National Sun Yat-Sen University, Kaohsiung 80424, \\ Taiwan \\ ${ }^{2}$ Department of Life Sciences, National Central University, Chungli 32001, Taiwan \\ ${ }^{3}$ Department of Landscape Architecture, National Chin-Yi University of Technology, Taichung \\ 41170, Taiwan \\ ${ }^{4}$ Global Institute for Energy, Environment and Sustainability, Kansas 66285, USA \\ *Corresponding author \\ e-mail:jkao@mail.nsysu.edu.tw \\ (Received 30 ${ }^{\text {th }}$ Nov 2016; accepted $27^{\text {th }}$ Feb 2017)
}

\begin{abstract}
In this study, effectiveness of using Pseudomonas mendocina NSYSU (P. mendocina NSYSU) on the bioremediation of octachlorinated dibenzofuran (OCDF)-polluted soils was evaluated through microcosm experiments and gene analys is under anaerobic conditions. The major tasks were to investigate the (1) feasibility of enhancing anaerobic OCDF dechlorination by P. mendocina NSYSU and lecithin, and (2) functional genes for the anaerobic biodegradation of OCDF. Results show that $P$. mendocina NSYSU was able to degrade OCDF through the anaerobic dechlorinating mechanisms. Results show that lecithin was used as the carbon source and OCDF desorption additive during the dechlorination of OCDF. Lecithin supplement could enhance the biodegradation rate of OCDF. Up to 68 and $61 \%$ of OCDF was removed after a 64-day operation with lecithin and nutrient broth supplement, respectively. Results indicate that primary substrate supplement is required for the enhancement of reductive dechlorination of OCDF. Five functional genes encoding the hydrolase in P. mendocina NSYSU were identified. The detected specific genes played important roles in OCDF dechlorination. Results reveal that a bioremediation system using $P$. mendocina NSYSU as the inocula would be a cost-effective and acceptable remedial system to remediate furan-polluted soils.
\end{abstract}

Keywords: microcosm; octachlorinated dibenzofuran (OCDF); Pseudomonas mendocina NSYSU; soil bioremediation; soil contamination

\section{Introduction}

Polychlorinated dibenzofuran (PCDF) isomers, which usually produce thermal processes, have been classified as the mutagens and carcinogens (Coutinho et al., 2015; Squadrone et al., 2015). Incinerators and boilers have been considered as the major causes of PCDFs production after waste burnings (Wittsiepe et al., 2015; Pongpiachan et al., 2016; Kruse et al., 2014; Klees et al., 2015). The production of PCDFs causes ecosystem and environmental media contamination (Shin et al., 2016; Wu et al., 2014; Hoogenboom et al., 2015; Yang et al., 2015). Different furan isomers including octachlorinated dibenzofuran (OCDF, a highly chlorinated furan), have been observed in different environmental media (e.g., sediments, soils) in many industrialized areas (Urban et al., 2014; Govindan and Moon, 2015).

As a result of their hydrophobic and xenobiotic nature, OCDFs are usually very persistent in ecosystems (Liu et al., 2014; Zhao et al., 2015). Due to their highly adsorptive, less biodegradable, and highly toxic natures, the remediation of PCDF-polluted media (e.g., soils, sediments) can be a necessity but costly (Zhao et al., 2015; Anasonye et al., 2014). Compared to physical and chemical remedial methods, the 
biological method can reduce the cleanup cost for the PCDF-polluted sites if significant amounts of media need to be remediated (Vallejo et al., 2015; Tue et al., 2016). The microbial species involved in bioremediation technologies include aerobic and anaerobic processes depending on the nature of contaminant and microorganisms (Megharaj et al., 2014). Compared to aerobic process, anaerobic bioremediation of PCDF-polluted media can be more energy saving, and thus, the operation and maintenance can be reduced (Hanano et al., 2014; Chen et al., 2016; Futagami et al., 2008; Lai and Becker, 2013; Liu et al., 2013).

During the reductive dechlorinating process, the perchlorinated substances act as terminal electron acceptors, which are a process of dehalorespiration (Liu et al., 2013; Zhen et al., 2014). The perchlorinated substances are degraded to less-chlorinated byproducts by anaerobic bacteria through dechlorinating mechanisms (Liu et al., 2014; Seshadri et al., 2005; Narihiro et al., 2010; Chen et al., 2013). There are two modes of reductive dehalogenation, called hydrogenolysis and dichloroelimination, but the biological process takes place mostly as the hydrogenolytic reaction (Mohn and Tiedje, 1992; Dolfing, 2003; Hiraishi, 2008; Urbaniak, 2013; Jeon et al., 2016). Many microbial strains apply contaminants as electron acceptors during dehalorespiration mechanisms under anaerobic processes (Nam et al., 2008; Bunge and Lechner, 2009; Ahn et al., 2005).

Stimulation of intrinsic microbial consortia of dehalogenating bacteria for chlorinated compounds biodegradation is a promising technology for the remediation of chlorinated compound-contaminated soils or sediments (Fennell et al., 2011; Kuokka et al., 2014a). Microbial species, which are related to Dehalococcoides, could motivate the reductive dechlorinating mechanisms to biotransform chlorinated furans to less-chlorinated furans (e.g., di or monochlorinated furans) (Zhen et al., 2014; Urbaniak, 2013; May et al., 2008). Biological dechlorinating process could be a feasible mechanism to reduce the toxicity and concentration of furan isomers (Liu et al., 2014; Bunge et al., 2003). Researchers reported that the reductive dechlorination activated by specific bacteria is a potential technique to dechlorinate highly halogenated furans (Narihiro et al., 2010; Kuokka et al., 2014b). In this process, gene analysis needs to be performed to investigate the feasibility of applying reductive dechlorination for PCDF degradation via assessing existence of specific and functional genes (Hanano et al., 2014; Liu et al., 2013; Bunge et al., 2003; Yoshida et al., 2005).

Supplement of carbon sources for the use of primary substrates is necessary to enhance the reductive dechlorinating mechanisms (Liu et al., 2014; Zhen et al., 2014; Kuokka et al., 2014a). Lecithin is an amphoteric emulsifier and rhizosphere phytogenic surfactant, which has relatively lower water solubility. Lecithin can serve as emulsification reagent, and depending on environmental conditions, its phospholipids can form liposomes or micelles (Abbasi and Radi, 2016; Miller, 2016). Thus, lecithin becomes an amphipathic biosurfactant, and also a good candidate of primary substrate during the reductive dechlorination of PCDF. Lecithin could enhance the bioaffinity and bioavailability of contaminant to bacteria after injection, and thus, the contaminant biodegradation rate could be enhanced (Paria, 2008; Schacht et al., 2016).

Currently, the information related to the biodegradation of higher chlorinated PCDFs under anaerobic conditions is limited (Liu et al., 2014; Kuokka et al., 2014a; Tu et al., 2014). A pentachlorophenol (PCP)-biodegrading bacterial strain, Pseudomonas mendocina NSYSU (P. mendocina NSYSU), was isolated from PCP, dioxin and furan-contaminated soils (Kao et al., 2005). The site was also polluted by OCDF with concentrations up to $10.8 \mathrm{mg} / \mathrm{kg}$ (NSC, 2012). In this study, a biodegradation study was performed to assess if $P$. mendocina NSYSU could bioremediate OCDF-polluted soils in an anaerobic system. The major tasks of this study were as follows: (1) evaluation of the feasibility of improving OCDF biodegradation by $P$. mendocina NSYSU under anaerobic conditions, (2) evaluation of the potential of using lecithin as the primary substrate for OCDF dechlorination, and (3) assessment of the existence of functional genes for the anaerobic OCDF biodegradation. 


\section{Materials and Methods}

\section{Incubation of P. mendocina NSYSU}

P. mendocina NSYSU culture was incubated in the anaerobic nutrient broth (NB) (Difco 003-01). The components of the NB solution included the following: yeast extract $1.5 \mathrm{~g} / \mathrm{L}$, beef extract $1.5 \mathrm{~g} / \mathrm{L}$, peptic digest $5 \mathrm{~g} / \mathrm{L}$, and $\mathrm{NaCl} 5 \mathrm{~g} / \mathrm{L}$. The peptic digest and beef extract in NB contained carbon and amino acids, which could be used for microorganisms as the primary substrates. The $P$. mendocina NSYSU solution was cultured at $200 \mathrm{rpm}$ for $48 \mathrm{~h}$ in a $50 \mathrm{~mL}$ flask (sealed with butyl rubber stopper) at $20^{\circ} \mathrm{C}$ under anaerobic conditions (purged with $100 \% \mathrm{~N}_{2}$ ). Density of the bacteria was analyzed by the spectrophotometer (Hach Co., USA).

\section{Batch study}

The biodegradability of OCDF under anaerobic conditions was investigated in the batch microcosm study. Soils from the OCDF-polluted site were situated in southern Taiwan and P. mendocina NSYSU were used as the inocula. In this study, lecithin, which was used as the primary substrate and solubilisation reagent, was supplied in the microcosms. Each batch bottle contained $1 \mathrm{~mL}$ of lecithin (or $1 \mathrm{~mL}$ of mineral medium solution), $20 \mathrm{~g}$ of site soils, $5 \mathrm{~mL}$ of $P$. mendocina NSYSU solution as inocula (or $5 \mathrm{~mL}$ of mineral solution), and $35 \mathrm{~mL}$ of nutrient mineral medium (autoclaved before use) in a 70-mL serum bottle, which was sealed with Teflon-lined rubber septa. The components of nutrient mineral solution (no carbon component) were described in Tu et al. (2014). The procedures of anaerobic microcosm preparation were described in Tu et al. (2014).

Table 1 lists the constituents of different microcosms. Group A was dead control group containing $500 \mathrm{mg} / \mathrm{L} \mathrm{NaN}_{3}$ and $250 \mathrm{mg} / \mathrm{L} \mathrm{HgCl}_{2}$, and the soils were autoclaved before use. Group B was live control group containing OCDF-polluted soils and $P$. mendocina NSYSU, but no NB addition. Group $\mathrm{C}$ was also live control group containing OCDF-polluted soils and NB, but no $P$. mendocina NSYSU addition. Dead (Group A) and live controls (Groups B and C) were prepared to assess the effects of NB and inocula addition on OCDF removal.

Table 1. Components of seven groups of microcosms.

\begin{tabular}{|c|c|c|}
\hline Microcosm & Inocula & Components \\
\hline $\begin{array}{c}\text { A } \\
(\text { Dead control) }\end{array}$ & Sterilized soils & $\begin{array}{c}\text { Sterilized OCDF-contaminated soils + nutrient medium } \\
\text { solution }+\mathrm{NB} \text { medium }+250 \mathrm{mg} / \mathrm{L} \mathrm{HgCl}_{2}+500 \mathrm{mg} / \mathrm{L} \\
\mathrm{NaN}_{3}\end{array}$ \\
\hline $\begin{array}{c}\text { B } \\
\text { (Control-no NB) } \\
\end{array}$ & $\begin{array}{c}\text { Soils }+P . \text { mendocina } \\
\text { NSYSU }\end{array}$ & $\begin{array}{l}\text { OCDF-contaminated soils + nutrient medium solution } \\
+P \text {. mendocina NSYSU (no NB medium) }\end{array}$ \\
\hline $\begin{array}{c}\mathrm{C} \\
\text { (Control-no strain) } \\
\end{array}$ & Soils & $\begin{array}{l}\text { OCDF-contaminated soils + nutrient medium solution } \\
+\mathrm{NB} \text { medium }\end{array}$ \\
\hline D & $\begin{array}{l}\text { Sterilized soils }+P \text {. } \\
\text { mendocina NSYSU }\end{array}$ & $\begin{array}{l}\text { Sterilized OCDF-contaminated soils + nutrient medium } \\
\text { solution }+P \text {. mendocina NSYSU + NB medium }\end{array}$ \\
\hline $\mathrm{E}$ & $\begin{array}{l}\text { Sterilized soils }+P \text {. } \\
\text { mendocina NSYSU }\end{array}$ & $\begin{array}{l}\text { Sterilized OCDF-contaminated soils + nutrient medium } \\
\text { solution }+P \text {. mendocina NSYSU + lecithin }\end{array}$ \\
\hline $\mathrm{F}$ & $\begin{array}{c}\text { Soils }+ \text { P. mendocina } \\
\text { NSYSU }\end{array}$ & $\begin{array}{l}\text { OCDF-contaminated soils + nutrient medium solution } \\
+P \text {. mendocina NSYSU + NB medium }\end{array}$ \\
\hline G & $\begin{array}{l}\text { Soils }+ \text { P. mendocina } \\
\text { NSYSU }\end{array}$ & $\begin{array}{c}\text { OCDF-contaminated soils }+P . \text { mendocina } \text { NSYSU + } \\
\text { nutrient medium solution }+ \text { lecithin }\end{array}$ \\
\hline
\end{tabular}

Group D microcosms contained sterilized soils and P. mendocina NSYSU, and Group E microcosms contained sterilized (autoclaved) soils, P. mendocina NSYSU, and one gram of lecithin. Group $\mathrm{F}$ microcosms contained unsterilized soils and $P$. mendocina NSYSU, and Group $\mathrm{G}$ microcosms contained unsterilized soils, $P$. 
mendocina NSYSU, and one gram of lecithin. P. mendocina NSYSU was incubated anaerobically in NB solution and the microcosms were operated at room temperature $\left(20^{\circ} \mathrm{C}\right)$. Duplicate samples were analyzed for OCDF concentrations for each sampling event. The degradation efficiency of OCDF was calculated as a percentage of the concentration on day 0 . The procedures for $P$. mendocina NSYSU incubation, soil extraction procedures, and OCDF analytical methods were described in Tu et al. (2014).

\section{PCR/DGGE analysis and gene identification}

Soil DNA extraction and the PCR amplification process were conducted using procedures in Baldwin et al. (2003) and Shrestha et al. (2010). Microcosm soils were applied for the PCR analyses to determine the bacteria in charge of the biodegradation of OCDF. Soil DNA extraction and the PCR amplification process were conducted using procedures in Ritalahti et al. (2006) and Shrestha et al. (2010). The primer sets were used to amplify genes encoding the dehalogenase of $P$. mendocina NSYSU (2011). The primer sets are listed in Table 2. The PCR-amplified products were sequenced, and the sequences were investigated by the alignment search tool for the determination of relatives in the GenBank (Yanru et al., 2005). The amplified PCR was also used for the conduction of denaturing gradient gel electrophoresis (DGGE) to evaluate the bacterial species and dominant bacteria. The DGGE procedures were described in Yanru et al. (2005).

\section{Results and Discussion}

In the batch microcosm study, OCDF-polluted soils (OCDF concentration $=10.8$ $\mathrm{mg} / \mathrm{kg}$ ) collected from the studied site were used for the remedial investigation. Fig. 1 presents the remained OCDF in Groups $A$ to $G$ microcosms during the 64-day incubation period. No significant OCDF removal [approximately $2 \%$ (Group A) to $6 \%$ (Group B) removal] was observed in control-no NB group (Group B), control-no strain (Group C), and dead-control group (Group A). The results reveal that when the soil bacteria were used as the inocula, effective OCDF biodegradation was not observed. This could be due to the fact that the furan-degrading microbial species were not the predominant bacteria in soils. Therefore, inoculation of specific bacteria would be required to improve the efficiency of OCDF biodegradation. Results show that the energy and carbon supplements were necessary to enhance the anaerobic dechlorination. Results demonstrate that OCDF could not be used as the carbon source by $P$. mendocina NSYSU or soil bacteria. Slight decrease in OCDF concentration in Group B (control-no NB) batch bottles was because natural organic carbon was consumed by $P$. mendocina NSYSU for primary substrate.

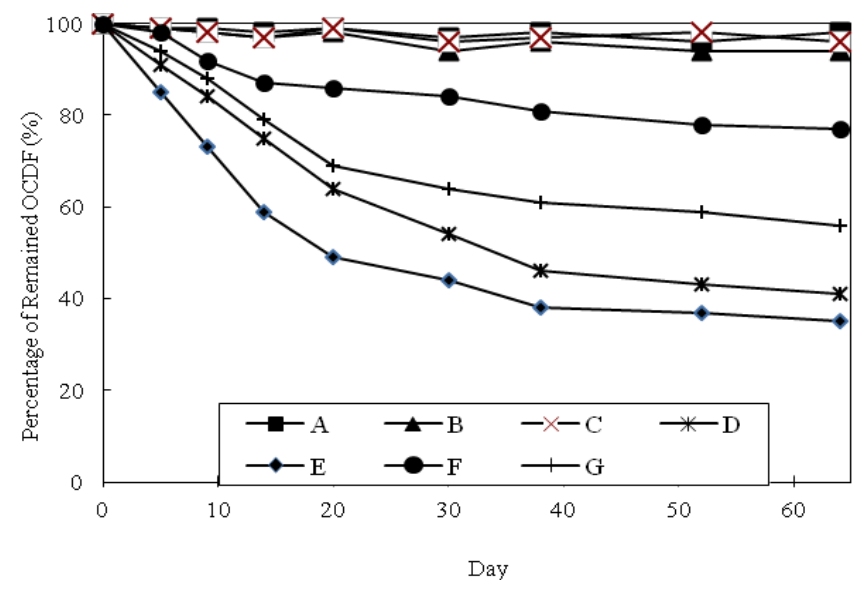

Figure 1. The remained $O C D F$ in microcosms during the 64-day incubation period. 
In Group D bottles (sterilized soils with P. mendocina NSYSU addition), significant drop of OCDF was observed and about 59\% of OCDF was degraded after 64 days. Results demonstrate that efficient OCDF biodegradation could be obtained anaerobically by $P$. mendocina NSYSU with the supplement of NB. The NB media had components of beef extract and peptic digest, which could be used as the carbon sources by $P$. mendocina NSYSU. Thus, OCDF could be dechlorinated through reductive dechlorination mechanisms using beef extract and peptic digest as the carbon sources. In Group F batch bottles (non-sterilized soils with P. mendocina NSYSU addition), relatively lower efficiency OCDF degradation (23\%) was detected. Results might be due to the fact that indigenous bacteria competed the supplied carbon sources with $P$. mendocina NSYSU resulting in the decreased efficiency of OCDF removal.

Table 2. Primer sets of genes encoding the dehalogenase of $P$. mendocina NSYSU.

\begin{tabular}{|c|c|}
\hline \multicolumn{2}{|c|}{ Target Gene } \\
\hline Pmen_0263 & $\begin{array}{l}\text { F:5'-G GCCGGCGACGACATCATCACCGACA } \\
\text { R:5'- CCCAGTCGAAGCCGGAACCACCGAC }\end{array}$ \\
\hline Pmen_1621 & $\begin{array}{c}\text { F:5'- GCGTGCCGCGCTGCACGGATG } \\
\text { R:5'- ACTCACGCAACACCGACAGCGGCTG }\end{array}$ \\
\hline Pmen_3718 & $\begin{array}{l}\text { F:5'- AGGCTGCGGCCAAGCATGCCTGGCT } \\
\text { R:5'- AGCTGACCGAGCTGCATGCGCAGGA }\end{array}$ \\
\hline Pmen_4219 & $\begin{array}{c}\text { F:5'- GGCAAGCTGGACGTGGTGGCCTA } \\
\text { R:5'- CGTTCGAGGGCGGTGGCGCGCAGTA }\end{array}$ \\
\hline Pmen_4457 & $\begin{array}{l}\text { F:5'- CTCGCCGAGTAGCTCCTCGCGGCTA } \\
\text { R:5'- ATCGACGAGCCGGATCTGACGGCGC }\end{array}$ \\
\hline
\end{tabular}

${ }^{1}$ Forward (-F) and reverse (-R) primers are indicated.

In Group E bottles (sterilized soils with $P$. mendocina NSYSU and lecithin supplement), about $65 \%$ of OCDF degradation was detected. Compared to results from Group D, lecithin supplement would improve the efficiency of OCDF degradation. The phospholipid structure in lecithin could form micelles, liposomes, and lamellar, and it is classified as amphipathic. Therefore, lecithin would enhance the affinity of OCDF to $P$. mendocina NSYSU, which results in the OCDF biodegradation efficiency.

In Group G microcosms (non-sterilized group with $P$. mendocina NSYSU and lecithin supplement), about $44 \%$ of OCDF drop was detected. Although lecithin supplement could enhance the OCDF solubilization, $P$. mendocina NSYSU was not the dominant microbial species in the system, and thus, indigenous soil bacteria would complete the carbon sources with $P$. mendocina NSYSU. This would result in the decrease in OCDF degradation rate. In this study, biodegradation byproducts were not observed (data not shown), which implies that produced byproducts might be biodegraded by $P$. mendocina NSYSU or other soil bacteria in non-sterilized groups.

Fig. 2 presents the DGGE patterns for soil samples collected from Group D bottles. The DGGE patterns show that the sterilized soil contained relatively lower bacterial diversities. Results also indicate that $P$. mendocina NSYSU was the dominant bacterial species after soil sterilization. Results reveal that the supplied $P$. mendocina NSYSU played a key role in OCDF biodegradation. Fig. 3 presents the DGGE patterns for soil samples collected from Group D bottles. The DGGE patterns show the non-sterilized soils contained higher bacterial species, and this could be because of the abundant indigenous bacterial diversities. Therefore, $P$. mendocina NSYSU was not the dominant bacterial strain in the microcosms. 


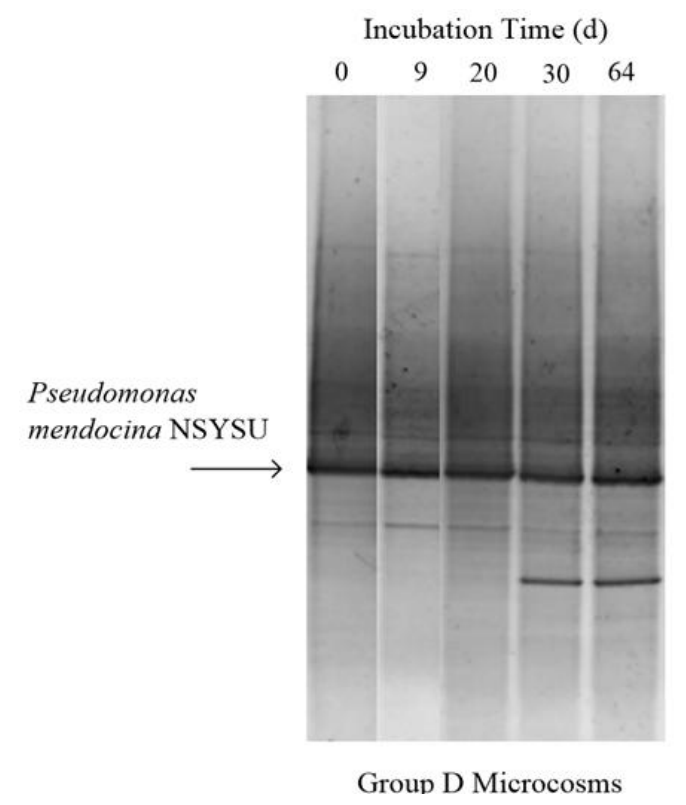

Figure 2. DGGE patterns for soil samples collected from Group D microcosms during the 64-day incubation period.

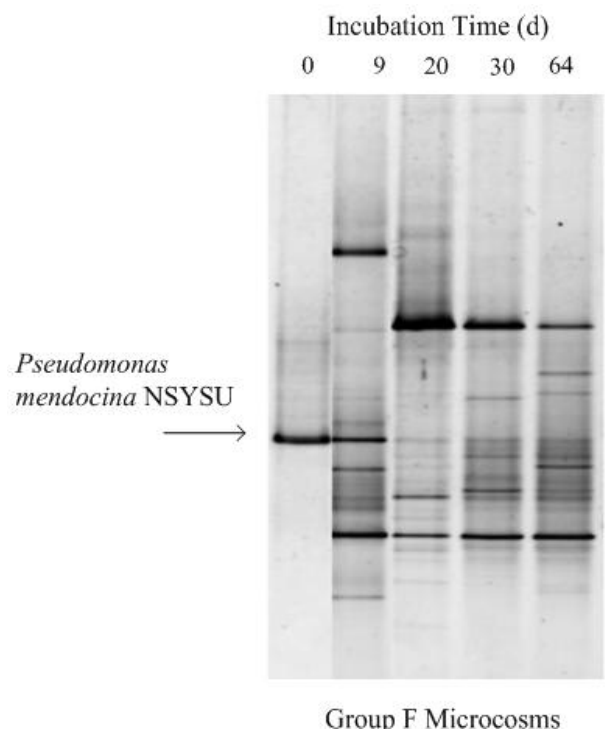

Figure 3. DGGE patterns for soil samples collected from Group F microcosms during the 64-day incubation period.

Results from Figs. 2-3 show that P. mendocina NSYSU bands in the DGGE pattern became less notable after 40 days of operation. This resulted in the decreased OCDF removal efficiency in the latter part of the study (Fig. 1). Results indicate that periodical inoculation of $P$. mendocina NSYSU to maintain a higher $P$. mendocina NSYSU population is required to obtain a high OCDF removal efficiency.

The occurrence and performance of functional genes of $P$. mendocina NSYSU were investigated for furan biodegradation. Five functional genes encoding the dehalogenase in $P$. mendocina NSYSU were determined (Genes 1-5). These functional genes are 
presented in Table 2. Results reveal that the anaerobic soils (Group F) contained five different $P$. mendocina DNA (five HAD family hydrolases) (Table 3). Fig. 4 presents the gel of PCR-amplified fragments for $P$. mendocina NSYSU and five HAD family hydrolases from Group $\mathrm{F}$ microcosm soils. Results demonstrate that the functional genes were in charge of biodegrading furan compounds under reductive dechlorinating mechanisms.

Table 3. Identified genes encoding the the dehalogenase of Pseudomonas mendocina NSYSU

\begin{tabular}{|c|l|c|c|c|}
\hline $\begin{array}{c}\text { Gene } \\
\text { No. }\end{array}$ & Gene name & $\begin{array}{c}\text { Gene length } \\
(\mathrm{bp})\end{array}$ & Gene description & $\begin{array}{c}\text { Similarity } \\
(\%)\end{array}$ \\
\hline Gene 1 & Pmen_0263 & 699 & HAD family hydrolase & 95 \\
\hline Gene 2 & Pmen_1621 & 693 & HAD family hydrolase & 97 \\
\hline Gene 3 & Pmen_3718 & 591 & HAD family hydrolase & 95 \\
\hline Gene 4 & Pmen_4219 & 651 & HAD family hydrolase & 97 \\
\hline Gene 5 & Pmen_4457 & 645 & HAD family hydrolase & 96 \\
\hline
\end{tabular}

${ }^{1}$ HAD family hydrolase: haloacid dehalogenase-like hydrolases.

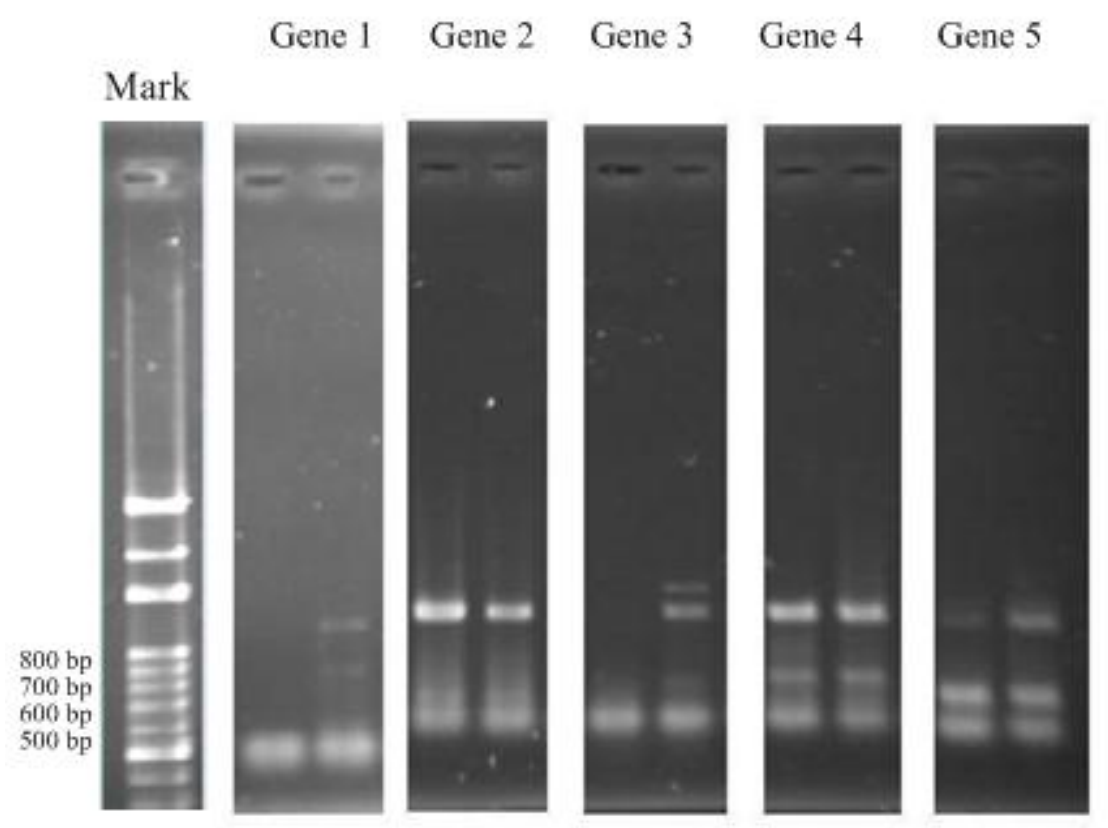

Figure 4. Gel showing the PCR-amplified fragments for genes encoding the dehalogenase of Pseudomonas mendocina NSYSU extracted from the soil samples on day 0 and day 40; $k b=$ kilobase

\section{Conclusions}

This study was conducted to evaluate the capability of $P$. mendocina NSYSU on the anaerobic biodegradation of OCDF. The dehalogenase genes, which had significant contributions to the reductive dechlorination of OCDF in $P$. mendocina NSYSU were investigated. Under reductive dechlorinating conditions, $P$. mendocina NSYSU had the capability to biodegrade OCDF. Lecithin could be used as the primary substrate and 
solubilization reagent resulting in increased solubilization and anaerobic biodegradation of OCDF. The removal efficiencies for OCDF reached 65 and 59\% in microcosms with and without the supplement of lecithin under anaerobic conditions, respectively.

PCR and DGGE results demonstrate that $P$. mendocina NSYSU was the dominant microbial species in sterilized soils during the operational period. Thus, $P$. mendocina NSYSU played a key role in OCDF degradation after soil sterilization. Under anaerobic conditions, five genes encoding the dehalogenase in $P$. mendocina NSYSU were identified, which were in charge of furan biodegradation. Results demonstrate that OCDF could not be used as the carbon source for P. mendocina NSYSU and indigenous soil bacteria under reductive dechlorinating conditions. Therefore, the addition of an appropriate substrate was required to enhance the OCDF biodegradation. Results reveal that an on-site bioreactor or in situ bioremediation using $P$. mendocina NSYSU as the inocula would be a cost-effective and acceptable remedial system to remediate furan-polluted soils.

\section{REFERENCES}

[1] Abbasi, S., Radi, M. (2016): Food grade microemulsion systems: Canola oil/lecithin:n-propanol/water. - Food Chem. 194: 972-979.

[2] Ahn, Y.B., Häggblom, M.M., Fennell, D.E. (2005): Co-amendment with halogenated compounds enhances anaerobic microbial dechlorination of 1,2,3,4-tetrachlorodibenzo-P-dioxin and 1,2,3,4-tetrachlorodibenzofuran in estuarine sediments. - Environ. Toxicol. Chem. 24: 2775-2784.

[3] Anasonye, F., Winquist, E., Kluczek-Turpeinen, B., Räsänen, M., Salonen, K., Steffen, K.T., Tuomela, M. (2014): Fungal enzyme production and biodegradation of polychlorinated dibenzo-p-dioxins and dibenzofurans in contaminated sawmill soil. Chemosphere 110: 85-90.

[4] Baldwin, B.R., Nakatsu, C.H, Nies, L. (2003): Detection and enumeration of aromatic oxygenase genes by multiplex and real-time PCR. - Appl. Environ. Microbiol. 69: 3350-3358.

[5] Bunge, M., Adrian, L., Kraus, A., Opel, M., Lorenz, W.G., Andreesen, J.R., Gorisch, H., Lechner, U. (2003): Reductive dehalogenation of chlorinated dioxins by an anaerobic bacterium. - Nature 421: 357-360.

[6] Bunge, M., Lechner, U. (2009): Anaerobic reductive dehalogenation of polychlorinated dioxins. - Appl. Microbiol. Biotechnol. 84: 429-444

[7] Chen, W.Y., Wu, J.H., Lin, S.C., Chang, J.E. (2016): Bioremediation of polychlorinated-p-dioxins/dibenzofurans contaminated soil using simulated compost-amended landfill reactors under hypoxic conditions. - J. Hazard. Mater. 312: 159-168.

[8] Chen, W.Y., Wu, J.H., Lin, Y.Y., Huang, H.J., Chang, J.E. (2013): Bioremediation potential of soil contaminated with highly substituted polychlorinated dibenzo-p-dioxins and dibenzofurans: microcosm study and microbial community analysis. - J Hazard Mater 261: 351-361.

[9] Coutinho, M., Albuquerque, M., Silva, A.P., Rodrigues, J., Borrego, C. (2015): Long-time monitoring of polychlorinated dibenzo-p-dioxins and dibenzofurans over a decade in the ambient air of Porto, Portugal. - Chemosphere 137: 207-213.

[10] Dolfing, J. (2003): Thermodynamic considerations for dehalogenation. - In: Häggblom, M.M., Bossert, I.D. (Eds.) Dehalogenation: Microbial Processes and Environmental Applications, 89-114.

[11] Fennell, D.E., Du, S., Liu, F., Liu, H., Häggblom, M.M. (2011): Dehalogenation of Polychlorinated Dibenzo-p-Dioxins and Dibenzofurans, Polychlorinated Biphenyls, and Brominated Flame Retardants, and Potential as a Bioremediation Strategy A2 - 
Moo-Young, Murray. Comprehensive Biotechnology (Second Edition). - Academic Press, Burlington, 135-149.

[12] Futagami, T., Goto, M., Furukawa, K. (2008): Biochemical and genetic bases of dehalorespiration. - The Chemical Record 8: 1-12.

[13] Govindan, M., Moon, I.S. (2015): Expeditious removal of PCDD/Fs from industrial waste incinerator fly ash using electrogenerated homogeneous $\mathrm{Ag}$ (II) ions. - Chem. Eng. J. 272: 145-150.

[14] Hanano, A., Almousally, I., Shaban, M. (2014): Phytotoxicity effects and biological responses of Arabidopsis thaliana to 2,3,7,8-tetrachlorinated dibenzo-p-dioxin exposure. Chemosphere 104: 76-84.

[15] Hiraishi, A. (2008): Biodiversity of Dehalorespiring Bacteria with Special Emphasis on Polychlorinated Biphenyl/Dioxin Dechlorinators. - Microbes and Environments 23: 1-12.

[16] Hoogenboom, R.L.A.P., Klop, A., Herbes, R., van Eijkeren, J.C.H., Zeilmaker, M.J., van Vuuren, A.M., Traag, W.A. (2015): Carry-over of polychlorinated dibenzo-p-dioxins and dibenzofurans (PCDD/Fs) and polychlorinated biphenyls (PCBs) in dairy cows fed smoke contaminated maize silage or sugar beet pulp. - Chemosphere 137: 214-220.

[17] Jeon, J.R., Murugesan, K., Baldrian, P., Schmidt, S., Chang, Y.S. (2016): Aerobic bacterial catabolism of persistent organic pollutants - potential impact of biotic and abiotic interaction. - Curr. Opin. Biotechnol. 38: 71-78.

[18] Kao, C.M., Liu, J.K., Chen, Y.L., Chai, C.T., Chen, S.C. (2005): Factors affecting the biodegradation of PCP by Pseudomonas mendocina NSYSU. - J. Hazard. Mater. 124: 68-73.

[19] Klees, M., Hiester, E., Bruckmann, P., Molt, K., Schmidt, T.C. (2015): Polychlorinated biphenyls, polychlorinated dibenzo-p-dioxins and dibenzofurans in street dust of North Rhine-Westphalia, Germany. - Sci. Total Environ. 511: 72-81.

[20] Kruse, N.A., Bowman, J., Lopez, D., Migliore, E., Jackson, G.P. (2014): Characterization and fate of polychlorinated biphenyls, polychlorinated dibenzo-p-dioxins and polychlorinated dibenzofurans in soils and sediments at the Portsmouth Gaseous Diffusion Plant, Ohio. - Chemosphere 114: 93-100.

[21] Kuokka, S., Rantalainen, A.L., Häggblom, M.M. (2014a): Anaerobic reductive dechlorination of 1,2,3,4-tetrachlorodibenzofuran in polychlorinated dibenzo-p-dioxinand dibenzofuran-contaminated sediments of the Kymijoki River, Finland. Chemosphere 98: 58-65.

[22] Kuokka, S., Rantalainen, A.L., Romantschuk, M., Häggblom, M.M. (2014b): Effect of temperature on the reductive dechlorination of 1,2,3,4-tetrachlorodibenzofuran in anaerobic PCDD/F-contaminated sediments. - J. Hazard. Mater. 274: 72-78.

[23] Lai, Y., Becker, J.G. (2013): Compounded Effects of Chlorinated Ethene Inhibition on Ecological Interactions and Population Abundance in a Dehalococcoides - Dehalobacter Coculture. - Environ. Sci. Technol. 47: 1518-1525.

[24] Liu, H., Park, J.-W., Fennell, D.E., Rodenburg, L.A., Verta, M., Häggblom, M.M. (2013): Microbially mediated reductive dechlorination of weathered polychlorinated dibenzofurans in Kymijoki sediment mesocosms. - Chemosphere 91: 212-221.

[25] Liu, H., Park, J.W., Häggblom, M.M. (2014). Enriching for microbial reductive dechlorination of polychlorinated dibenzo-p-dioxins and dibenzofurans. - Environ. Pollut. 184: 222-230.

[26] May, H.D., Miller, G.S., Kjellerup, B.V., Sowers, K.R. (2008): Dehalorespiration with Polychlorinated Biphenyls by an Anaerobic Ultramicrobacterium. - Appl. Environ. Microbiol. 74: 2089-2094.

[27] Megharaj, M., Venkateswarlu, K., Naidu, R. (2014): Bioremediation A2 - Wexler, Philip. Encyclopedia of Toxicology (Third Edition). - Academic Press, Oxford, 485-489.

[28] Miller, R. (2016): Emulsifiers: Types and Uses. Encyclopedia of Food and Health. Academic Press, Oxford, 498-502. 
[29] Mohn, W.W., Tiedje, J.M. (1992): Microbial reductive dehalogenation. - Microbiol. Rev. 56: 482-507.

[30] Nam, I.H., Kim, Y.M., Murugesan, K., Jeon, J.R., Chang, Y.Y., Chang, Y.S. (2008): Bioremediation of PCDD/Fs-contaminated municipal solid waste incinerator fly ash by a potent microbial biocatalyst. - J Hazard Mater 157: 114-121.

[31] Narihiro, T., Kaiya, S., Futamata, H., Hiraishi, A. (2010): Removal of polychlorinated dioxins by semi-aerobic fed-batch composting with biostimulation of "Dehalococcoides". - J. Biosci. Bioeng. 109: 249-256.

[32] National Center for Biotechnology Information (NCBI), (2011): Complete sequence of Pseudomonas mendocina ymp, http://www.ncbi.nlm.nih.gov/nuccore/145573243.

[33] NSC, (2012): Development of Treatment Technologies to Remediate Toxic Chemical Contaminated Sites. - National Science Council, Taipei, Taiwan Report No. 101-2622-E-006-001-C-C1.

[34] Paria, S. (2008): Surfactant-enhanced remediation of organic contaminated soil and water. - Adv. Colloid Interface Sci. 138: 24-58.

[35] Pongpiachan, S., Wiriwutikorn, T., Rungruang, C., Yodden, K., Duangdee, N., Sbrilli, A., Gobbi, M., Centeno, C. (2016): Impacts of micro-emulsion system on polychlorinated dibenzo-p-dioxins (PCDDs) and polychlorinated dibenzofurans (PCDFs) reduction from industrial boilers. - Fuel 172: 58-64.

[36] Ritalahti, K.M., Amos, B.K., Sung, Y., Wu, Q., Koenigsberg, S.S., Löffler, F.E. (2006): Quantitative PCR targeting 16S rRNA and reductive dehalogenase genes simultaneously monitors multiple Dehalococcoides strains. - Applied and Environmental Microbiology 72(4): 2765-2774.

[37] Schacht, V.J., Grant, S.C., Escher, B.I., Hawker, D.W., Gaus, C. (2016): Solubility enhancement of dioxins and PCBs by surfactant monomers and micelles quantified with polymer depletion techniques. - Chemosphere 152: 99-106.

[38] Seshadri, R., Adrian, L., Fouts, D.E., Eisen, J.A., Phillippy, A.M., Methe, B.A., Ward, N.L., Nelson, W.C., Deboy, R.T., Khouri, H.M., Kolonay, J.F., Dodson, R.J., Daugherty, S.C., Brinkac, L.M., Sullivan, S.A., Madupu, R., Nelson, K.E., Kang, K.H., Impraim, M., Tran, K., Robinson, J.M., Forberger, H.A., Fraser, C.M., Zinder, S.H., Heidelberg, J.F. (2005): Genome Sequence of the PCE-Dechlorinating Bacterium Dehalococcoides ethenogenes. - Science 307: 105-108.

[39] Shin, E.S., Kim, J.C., Choi, S.D., Kang, Y.W., Chang, Y.S. (2016): Estimated dietary intake and risk assessment of polychlorinated dibenzo-p-dioxins and dibenzofurans and dioxin-like polychlorinated biphenyls from fish consumption in the Korean general population. - Chemosphere 146: 419-425.

[40] Shrestha, H.K., Hwu, K.K., Chang, M.C. (2010): Advances in detection of genetically engineered crops by multiplex polymerase chain reaction methods. - Trends Food Sci. Technol. 21: 442-454.

[41] Squadrone, S., Brizio, P., Nespoli, R., Stella, C., Abete, M.C. (2015): Human dietary exposure and levels of polychlorinated dibenzo-p-dioxins (PCDDs), polychlorinated dibenzofurans (PCDFs), dioxin-like polychlorinated biphenyls (DL-PCBs) and non-dioxin-like polychlorinated biphenyls (NDL-PCBs) in free-range eggs close to a secondary aluminum smelter, Northern Italy. - Environ. Pollut. 206: 429-436.

[42] Tu, Y.T., Liu, J.K., Lin, W.C., Lin, J.L., Kao, C.M. (2014): Enhanced anaerobic biodegradation of OCDD-contaminated soils by Pseudomonas mendocina NSYSU: Microcosm, pilot-scale, and gene studies. - J. Hazard. Mater. 278: 433-443.

[43] Tue, N.M., Goto, A., Takahashi, S., Itai, T., Asante, K.A., Kunisue, T., Tanabe, S. (2016): Release of chlorinated, brominated and mixed halogenated dioxin-related compounds to soils from open burning of e-waste in Agbogbloshie (Accra, Ghana). - J. Hazard. Mater. 302: 151-157.

[44] Urban, J.D., Wikoff, D.S., Bunch, A.T.G., Harris, M.A., Haws, L.C. (2014): A review of background dioxin concentrations in urban/suburban and rural soils across the United 
States: Implications for site assessments and the establishment of soil cleanup levels. Sci. Total Environ. 466-467, 586-597.

[45] Urbaniak, M. (2013): Biodegradation of PCDDs/PCDFs and PCBs. - In: Chamy, R. (Ed.) Biodegradation - Engineering and technology. InTech, Rijeka, Croatia, 73-100.

[46] Vallejo, M., Fresnedo San Román, M., Ortiz, I., Irabien, A. (2015): Overview of the PCDD/Fs degradation potential and formation risk in the application of advanced oxidation processes (AOPs) to wastewater treatment. - Chemosphere 118: 44-56.

[47] Wittsiepe, J., Fobil, J.N., Till, H., Burchard, G.-D., Wilhelm, M., Feldt, T. (2015): Levels of polychlorinated dibenzo-p-dioxins, dibenzofurans (PCDD/Fs) and biphenyls (PCBs) in blood of informal e-waste recycling workers from Agbogbloshie, Ghana, and controls. Environ. Int. 79: 65-73.

[48] Wu, T.W., Lee, J.W., Liu, H.Y., Lin, W.H., Chu, C.Y., Lin, S.L., Chang-Chien, G.P., Yu, C. (2014): Accumulation and elimination of polychlorinated dibenzo-p-dioxins and dibenzofurans in mule ducks. - Sci. Total Environ. 497-498, 260-266.

[49] Yang, C.Y., Chiou, S.L., Wang, J.D., Guo, Y.L.L. (2015): Health related quality of life and polychlorinated biphenyls and dibenzofurans exposure: 30 years follow-up of Yucheng cohort. - Environ. Res. 137: 59-64.

[50] Yanru, Y., Manuel, P., William, S., Josef, Z. (2005): Identification of microorganisms involved in reductive dehalogenation of chlorinated ethenes in an anaerobic microbial community. - Water Res. 39: 3954-3966.

[51] Yoshida, N., Takahashi, N., Hiraishi, A. (2005): Phylogenetic characterization of a polychlorinated-dioxin-dechlorinating microbial community by use of microcosm studies. - Appl. Environ. Microbiol. 71: 4325-4334.

[52] Zhao, L., Hou, H., Zhu, T., Li, F., Terada, A., Hosomi, M. (2015): Successive self-propagating sintering process using carbonaceous materials: A novel low-cost remediation approach for dioxin-contaminated solids. - J. Hazard. Mater. 299: 231-240.

[53] Zhen, H., Du, S., Rodenburg, L.A., Mainelis, G., Fennell, D.E. (2014): Reductive dechlorination of 1,2,3,7,8-pentachlorodibenzo-p-dioxin and Aroclor 1260, 1254 and 1242 by a mixed culture containing Dehalococcoides mecartyi strain 195. - Water Res. 52: 51-62. 